\title{
Oral manifestations of Crohn's disease
}

\author{
Henedina Antunes, ${ }^{1,2,3}$ Cláudia Patraquim, ${ }^{5}$ Vera Baptista, ${ }^{4}$ Luís Silva Monteiro ${ }^{5}$
}

${ }^{1}$ Gastroenterology, Hepatology and Nutrition Unit, Department of Pediatrics, Hospital de Braga, Braga, Portugal ${ }^{2}$ Life and Health Sciences Research Institute (ICVS), School of Health Sciences, University of Minho, Braga, Portugal

${ }^{3}$ ICVS/3B's_-PT Government Associate Laboratory, University of Minho, Braga/Guimarães, Portugal

${ }^{4}$ Department of Pediatrics, Hospital de Braga, Braga, Portugal

${ }^{5}$ Department of Medicine and Oral Surgery, Instituto Superior de Ciências da Saúde Norte, CESPU, Paredes, Portugal

\section{Correspondence to}

Professor Henedina Antunes, henedinaantunes@gmail.com

Accepted 6 October 2015
CrossMark

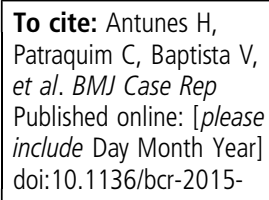

\section{DESCRIPTION}

A 17-year-old boy presented with a 2-month history of painful oral ulcerated lesions and cheilitis (figure 1A-C), with no other symptoms, and no history of trauma or toxic ingestion. His and family medical history were not relevant.

A biopsy of the oral lesions showed lymphoplasmacytic infiltrate and epithelioid granulomas, compatible with Crohn's disease (CD) (figure 2).

Three months after onset of the oral lesions, the patient started experiencing intermittent abdominal pain and mentioned a change in bowel habits, with loose stools. On examination, he had oral ulcerations, cheilitis and anal skin tags.

Blood analyses showed elevation of erythrocyte sedimentation rate and $\mathrm{C}$ reactive protein, and
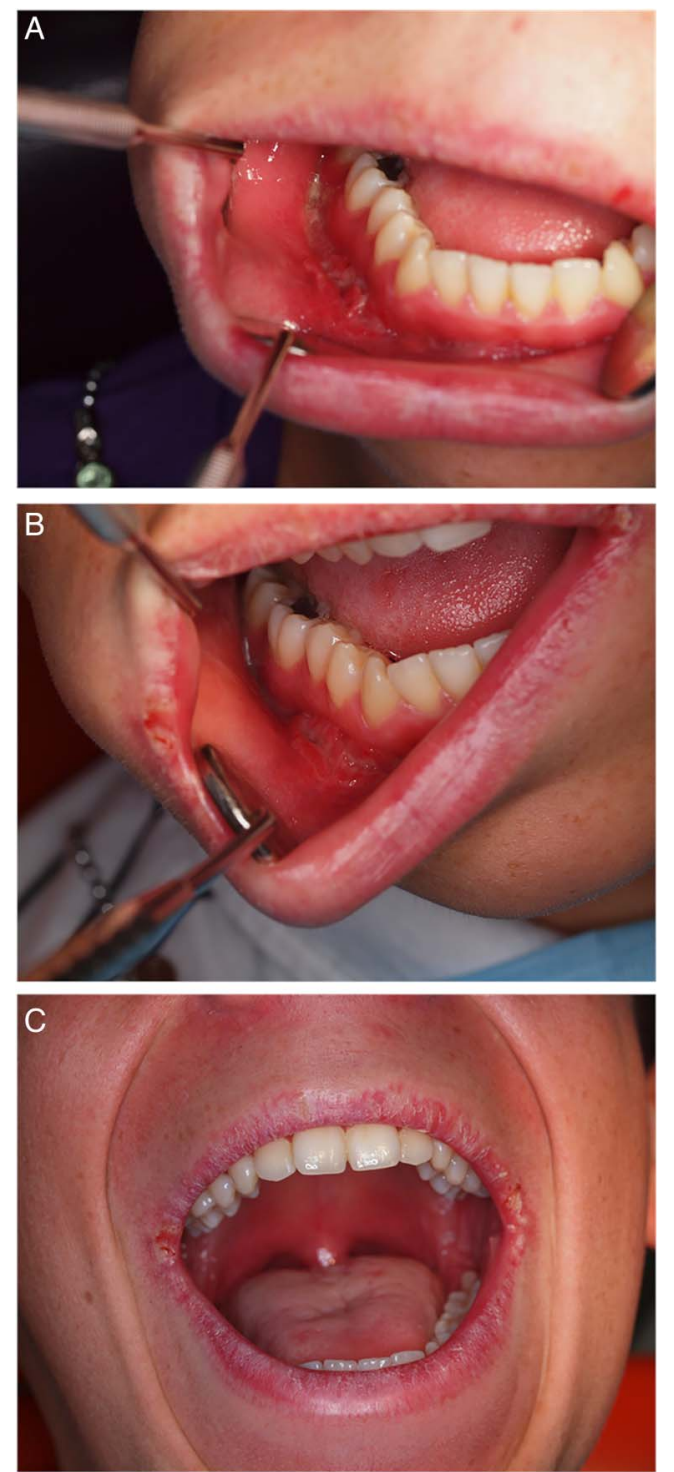

Figure $1 \quad(A-C)$ Oral ulcerated lesions and cheilitis.

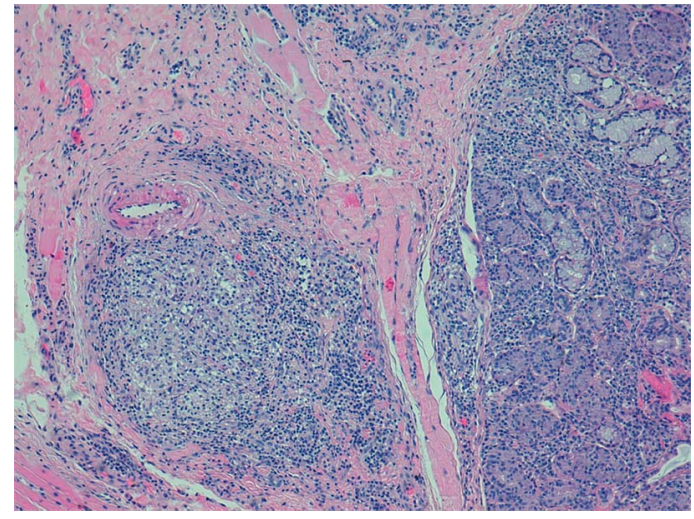

Figure 2 Microscopic image ( $\mathrm{H} \& \mathrm{E}, \times 100$ magnification) showing epithelioid granulomas in specimen of oral biopsy.
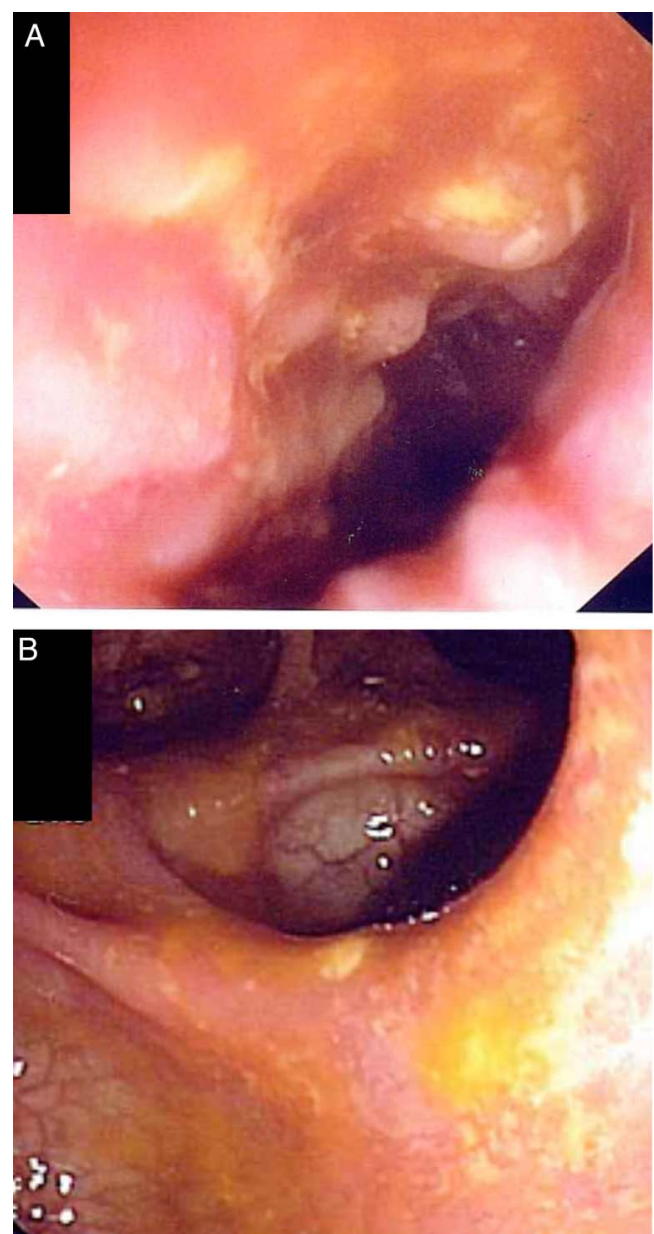

Figure 3 ( $A$ and B) Gross endoscopic appearance of terminal ileum showing cobblestone change of the mucosa (fissures and ulcers separate islands of more intact mucosal epithelium) (A), and mucosal ulcerations close to the ileocaecal valve (B). 

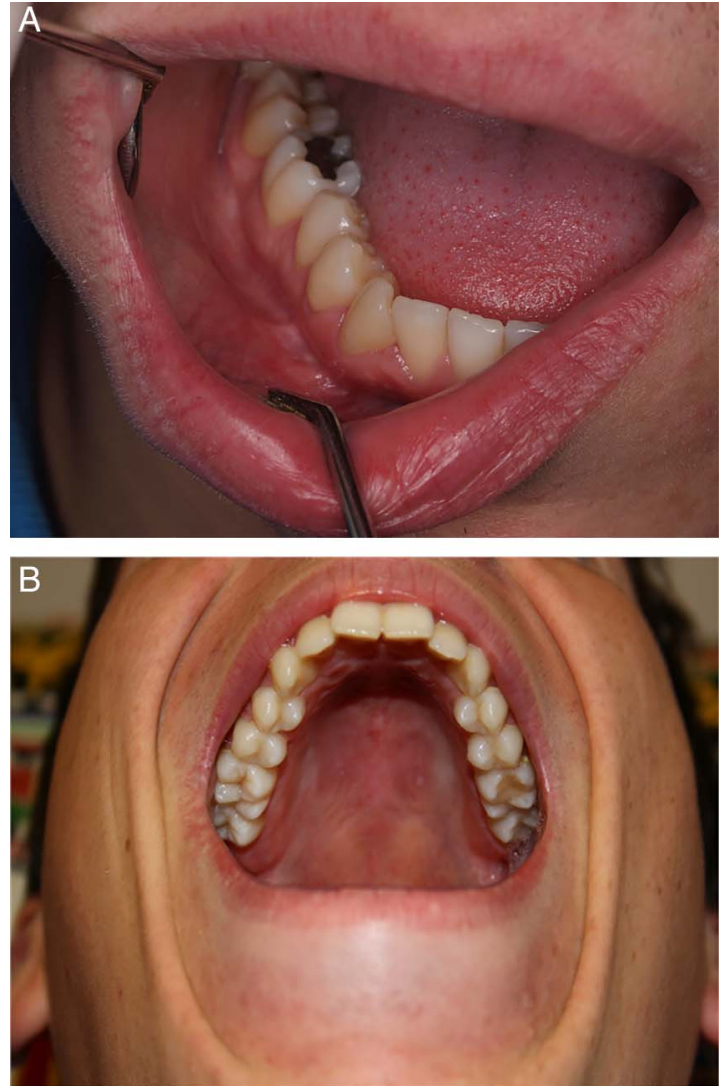

Figure 4 ( $A$ and $B$ ) Visible improvement of oral ulcerated lesions (A), and cheilitis (B), after initiation of treatment.

positive anti-Saccharomyces cerevisiae antibody. Upper gastrointestinal endoscopy was normal. Ileocolonoscopy revealed ileocaecal valve deformation, and ileum and colon ulcerations (figure 3A, B). Biopsies of intestinal mucosa showed architectural distortion, inflammatory infiltrate with granulation tissue and epithelioid granulomas, typical features of CD.

Four weeks after initiation of oral treatment with $40 \mathrm{mg}$ of prednisolone and $100 \mathrm{mg}$ of azathioprine daily, the patient's oral lesions had significantly improved (figure 4A, B), as had his gastrointestinal symptoms.
$\mathrm{CD}$ is a chronic inflammatory process that can involve any region of the alimentary tract. ${ }^{1}$ Clinical presentation is variable and less typical, and extraintestinal manifestations may precede and dominate the clinical picture. ${ }^{2}$

CD should be considered in the differential diagnosis of every child with orofacial granulomatosis (OFG). Long-term follow-up is required for patients with OFG as they may develop intestinal $\mathrm{CD}$ at a later stage. ${ }^{3}$

This case illustrates the importance of clinical suspicion for $\mathrm{CD}$ in patients, particularly children, with OFG.

\section{Learning points}

- Crohn's disease is a chronic inflammatory process that can involve any part of the gastrointestinal tract.

- Less common or extraintestinal manifestations may precede and dominate the clinical picture.

- Crohn's disease should be hypothesised in every child with orofacial granulomatosis.

Acknowledgements The authors would like to thank Dr Joana Pardal for providing the microscopic image.

Contributors All the authors contributed to the diagnosis, treatment, literature research and conception of the paper. HA was responsible for the ileocolonoscopy and intestinal biopsies. LSM was responsible for the oral biopsies. All the authors revised the final version of the article.

Competing interests None declared.

Patient consent Obtained.

Provenance and peer review Not commissioned; externally peer reviewed.

\section{REFERENCES}

1 Freeman HJ. Natural history and long-term clinical course of Crohn's disease. World J Gastroenterol 2014;20:31-6

2 Levine A, Koletzko S, Turner D, et al, European Society of Pediatric Gastroenterology, Hepatology, and Nutrition. ESPGHAN revised porto criteria for the diagnosis of inflammatory bowel disease in children and adolescents. J Pediatr Gastroenterol Nutr 2014;58:795-806.

3 Lazzerini M, Bramuzzo M, Ventura A. Association between orofacial granulomatosis and Crohn's disease in children: systematic review. World I Gastroenterol 2014;20:7497-504.

Copyright 2015 BMJ Publishing Group. All rights reserved. For permission to reuse any of this content visit http://group.bmj.com/group/rights-licensing/permissions.

BMJ Case Report Fellows may re-use this article for personal use and teaching without any further permission.

Become a Fellow of BMJ Case Reports today and you can:

- Submit as many cases as you like

- Enjoy fast sympathetic peer review and rapid publication of accepted articles

- Access all the published articles

- Re-use any of the published material for personal use and teaching without further permission

For information on Institutional Fellowships contact consortiasales@bmjgroup.com

Visit casereports.bmj.com for more articles like this and to become a Fellow 